TITLE: Biotic and Abiotic Carbon To Sulfur Bond Cleavage

P.l.: John W. Frost, Associate Professor

$\mathrm{DOE} / \mathrm{PC} / 90294-\mathrm{Tl}$

STUDENTS: Kurt Stimpfl and Bernard Heymann, Ph.D. Candidates

INSTITUTION: Purdue University, West Lafayette, IN 47907

DE92 012640

GRANT NO.: DE-FG22-90PC90294

Cleavage of aliphatic organosulfonate carbon to sulfur (C-S) bonds, a critical link in the global biogeochemical sulfur cycle, ${ }^{1,2}$ has been identified in Escherichia coli $\mathbf{K}-12$. Enormous quantities of inorganic sulfate are continuously converted (Scheme I) into methanesulfonic acid 1 and acylated 3-(6-sulfo- $\alpha$-D-quinovopyranosyl)-L-glycerol 2.,.$^{1,3}$ Biocal lytic desulfurization (Scheme I) of 1 and 3, which share the structural feature of an aliphatic carbon bonded to a sulfonic acid sulfur, completes the cycle. Discovery of this desulfurization in $E$. coli provides an invaluable paradigm for study of a biotic process which, via the biogeochemical sulfur cycle, significantly influences the atmospheric concentration of sulfur-containing molecules. ${ }^{2}$

\title{
SCHEME I
}

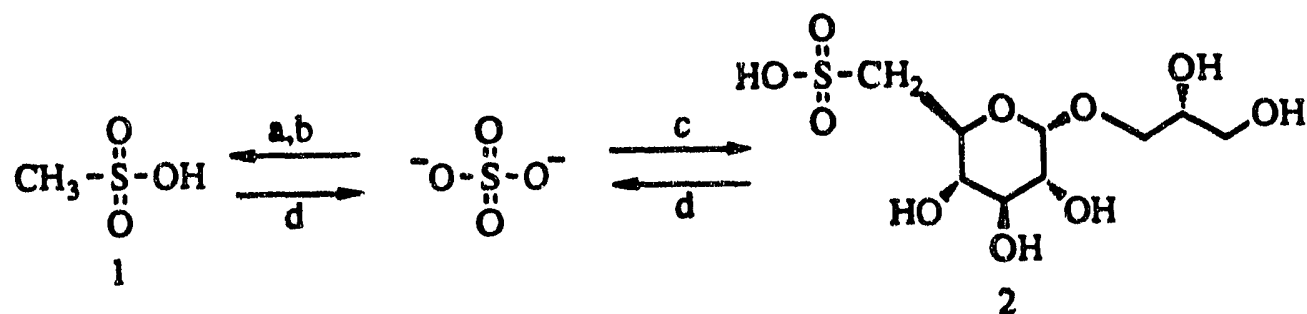
a. biocalalysis (bacteria, plants, algae)
c. biocatalysis (plants)
b. photolysis
d. biocatalysis (bacteria)

Desulfurizations of aliphatic organosulfonates and aromatic organosulfonates constitute the major classes of biocatalytic organosulfonate $C-S$ bond cleavage processes. Forcing E. col: $K-12$ to use aliphatic organosulfonates (Table I) as a sulfur source revealed capabilities broadly reminiscent of desulfurizations catalyzed by bacteria isolated from soi i and harbor water. ${ }^{4}$ Formation of $\left[{ }^{14} \mathrm{C}\right]-$ carbon dioxide from $\left[{ }^{14} \mathrm{C}\right]$-methanesulfonic acid is similar to a recently discovered transformation effected by soil bacteria. ${ }^{2}$ However, not all urganosulfonate $C-S$ bond cleavage processes are present in $E$. coli. Failure to degrade berizenesulfonate distinguishes $E$. coli from bacteria which are capable of cleaving aromatic organosulfonate $C-S$ bonds. ${ }^{5,6}$ 
Table I. Comparison of Biocatalytic Aliphatic Organosulfonate C-S Bond Cleavage Reactions

\begin{tabular}{|c|c|c|c|c|c|}
\hline \multirow[b]{2}{*}{ organosulfonate } & \multirow[b]{2}{*}{ growth" } & \multirow{2}{*}{$\begin{array}{c}\text { specific } \\
\text { activity } \\
10^{-4} \text { units/mg }\end{array}$} & \multicolumn{2}{|c|}{ products $^{\mathrm{c}}$} & \\
\hline & & & intact cells & lysate & \\
\hline${ }^{14} \mathrm{CH}_{3} \mathrm{SO}_{3} \mathrm{H}$ & + & 0.35 & ${ }^{14} \mathrm{CO}_{2}$ & $N D^{d}$ & \\
\hline \multirow[t]{3}{*}{$\mathrm{CH}_{3}\left(\mathrm{CH}_{2}\right)_{5} \mathrm{SO}_{3} \mathrm{H}$} & + & 3.3 & $\mathrm{CH}_{3}\left(\mathrm{CH}_{2}\right)_{5} \mathrm{OH}$ & $\mathrm{CH}_{3}\left(\mathrm{CH}_{2}\right.$ & $\mathrm{O}_{2} \mathrm{H}$ \\
\hline & - & $\mathbf{x}$ & $\mathbf{x}$ & $\mathbf{x}$ & \\
\hline & - & 0.29 & $\mathbf{x}$ & & \\
\hline $\mathrm{n}=1$ & + & 5.4 & $\mathrm{n}=1$ & & $\mathrm{n}=0$ \\
\hline $\mathrm{n}=2$ & + & 9.0 & $\mathrm{n}=2$ & & $\mathrm{n}=1$ \\
\hline $\mathrm{n}=3$ & + & 6.4 & $n=3$ & & $n=2$ \\
\hline
\end{tabular}

a E. coli RB791 (W31110 lacL819) ${ }^{9}$ were cultured at $37^{\circ} \mathrm{C}$ for $14 \mathrm{~h}$ in $\mathrm{M} 9$ minimal medium ${ }^{8}$ supplemented with thiamine hydrochloride $(0.005 \mathrm{~g} / \mathrm{L})$ and with organosulfonic acid $(0.25 \mathrm{mM})$ replacing inorganic sulfate. ${ }^{b} 1$ unit $=1 \mu \mathrm{mol} \mathrm{SO}_{3}{ }^{-2} / \mathrm{min}$; Assay solutions ( $\mathrm{pH} 8.8$ ) consisted of protein $(10-14 \mathrm{mg} / \mathrm{mL})$ from desalted cell lysate incubated with trizma $\mathrm{HCl}(63 \mathrm{mM})$, sodium chloride $(9$ $\mathrm{mM})$, ammonium chloride (19 mM), NADH (10 mM), and organosulfonate (12.5 mM). Aliquots (1 $\mathrm{mL}$ ) were removed at timed intervals and protein precipitated with $10 \%(\mathrm{w} / \mathrm{v})$ trichloroacetic acid. Absorbance $(412 \mathrm{~nm})$ was measured after incubation of neutralized, deproteinized aliquots with Ellman's reagent. ${ }^{c}$ Chloroform extracts of culture supernatants and cell lysates were analyzed by gas chromatography and GC-MS. Structure assignments were based on coinjection with authentic samples and comparison of mass spectra. ${ }^{d}$ not determined

Extracellular accumulation of 2-phenylethan-1-ol and trace levels of phenylacetic acid in the supernatant of $E$. coli cultured with 2-phenyl-1-ethanesulfonic acid were characteristic of the carbon fragments formed from the aliphatic organosulfonates (Table I). To ascertain whether the alcohols were the actual carbon fragments initially formed by $\mathrm{C}-\mathrm{S}$ bond cieavage, desulfurization of 2 -phenyl- 
1,1-dideutero-1-ethanesulfonic acid by intact $E$. coli was examined. Retention of only one deuterium in product 2-phenyl-1-deuteroethan-1-ol implicated aldehyde intermediacy despite the absence of aldehyde products in cell lysate and culture supernatants. This eliminated direct hydrolysis ${ }^{9}$ (Path A; Scheme II) and insertion of oxygen into the C-S bond (Path B; Scheme II) as mechanistic possibilities.

SCHEME II
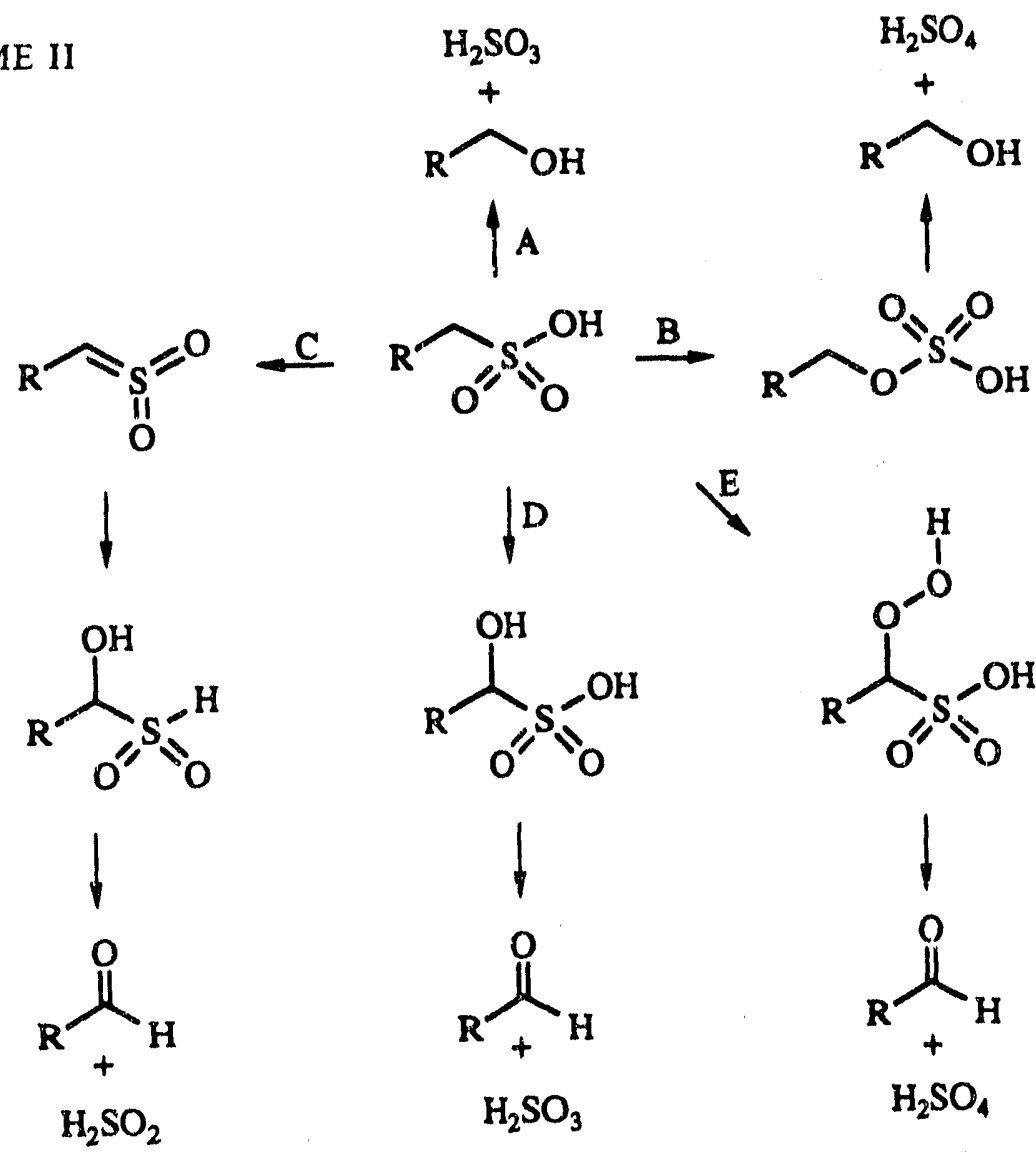

Although no, $\mathrm{C}-\mathrm{S}$ bond cleavage of organosulfonates was detectable in anaerobic desalted cell lysate, aeration and addition of reduced nicotinamide adenine dinucleotide (NADH) resulted in desulfurization. Formation of phenylacetic acid and phenyl-2-propanone from 2-phenyl-1ethanesulfonic acid and 1-phenyl-2-propanesulfonic acid were typical (Table 1) of the cell-free desulfurizations. The NADH and oxygen requirement for cell-free C-S cleavage activity effectively removed sulfene intermediacy ${ }^{10}$ (Path C; Scheme II) from further consideration. Formation of 5- 
thio-2-nitrobenzoate when Ellman's reagent was added to deproteinized assay aliquots implicated sulfite formation and was used to determine enzyme specific activities (Table 1). ${ }^{11}$ This eliminates all mechanisms leading to inorganic sulfate ${ }^{12}$ (Path E, Scheme II) and leaves $\alpha$-hydroxylation (Path D, Scheme II) as the only remaining, viable mechanism.

For the present, scrutiny of the products, intermediates, and mechanism of aliphatic organosulfonate desulfurization in $E$. coli has provided key insights into an intriguing yet largely uncharacterized biocatalytic transformation. The next level of appraisal requires purification of the enzyme responsible for aliphatic organosulfonate $C-S$ bond cleavage. Such efforts must contend with the low specific activities in cell lysate and chronic enzyme instability. Fortunately, the relative ease with which soluble enzymes can be overproduced in E. coli and observed stabilization of C-S bond cleaving activity with NADH and argon atmosphere ${ }^{13}$ should expedite future manipulations of the enzyme.

Acknowledgment. Research was supported by Department of Energy Contract No. DE-FG22-90PC90294.

\section{REFERENCES}

1. Baker, S. C.; Kelly D. P.; Murrell, J. C. Nature 1991, 350, 627.

2. Kelly, D. P.; Smith, N. A. Adv. Microb. Ecol. 1990, 11, 345.

3. Harwood, J. L.; Nicholls, R. G. Biochem. Soc. Trans. 1979, 7, 440

4. (a) Thysse, G. J. E.; Wanders, T. H. Antonie van Leeuwenhoek 1972, 38, 53. (b) Thysse, G. J. E.; Wanders, T. H. Anlonie van Leeuwenhoek 197, 40, 25. (c) Biedlingmaier, S.; Schmidt, A. Arch. Microbiol. 1983, 136, 124. (d) Biedlingmaier, S.; Schmidt, A. Z. Naturforsch. 1987, 42c, 891.

5. For aromatic organosulfonate C-S bond cleavage in cell-free lysate, see: (a) Locher, H. H.; Leisinger, T.; Cook, A. M. Biochem. J 1991, 274, 833. (b) Thurnheer, T.; Zthrrer, D.; Hobglinger, O.; Leisinger, T.; Cook, A. M. Biodegradation 1990, l, 55. (c) Locher, H. H.; Leisinger, T.; Cook, A. M. J. Gen. Microbiol. 1989, 135, 1969. (d) Thurnheer, T.; Kohler, T.; Cook, A. M.; Leisinger, T. J. Gen. 
Microbiol. 1986, 132, 1215.

6. For a general review, see: Swisher, R. D. Surfactant Biodegradation; Marcel Dekker: New York, 1987.

7. Frost, J. W.; Bender, J. L.; Kadonaga, J. T.; Knowles, J. R. Biochemistry 1984, 23, 4470.

8. Miller, J. H. Experiments in Molecular Genetics; Cold Spring Harbor Laboratory: Cold Spring Harbor, 1972; pp 431.

9. (a) Wagner, F. C.; Reid, E. E. J. Am. Chem. Soc. 1931, 53, 3407. (b) Brindley, P. B. J. Chem. Soc. C 1966, 163.

10. This process was hypothesized to possibly involve adenyl transfer to the sulfonic acid catalyzed by ATP sulfurylase, ${ }^{a}$ subsequent elimination to generate APS along with a sulfene, ${ }^{b-d}$ and final hydrolysis. (a) Leyh, T. S.; Taylor, J. C.; Markham, G. D. J. Biol. Chem. 1988, 263, 2409. (b) Wallace, T.J. Quart. Rev. 1966, 20, 67. (c) Opitz, G. Ang. Chem. Int. Ed. 1967, 6, 107. (d) King, J. F. Acc. Chem. Res. 1975, 8, 10.

11. Humphrey, R. E.; Ward, M. H.; Hinze, W'. Anal. Chem. 1970, 42, 698.

12. No reduction of inorganic sulfate to sulfite was observed in cell lysates

13. No appreciable loss of enzyme activity is observed over a $270 \mathrm{~h}$ period when cell lysate in the standard assay solution lacking organosulf onate is maintained under argon. Removal of NADH along with exposure to air results in a $90 \%$ loss of enzyme activity within $5 \mathrm{~h}$

\section{DISCLAIMER}

This report was prepared as an account of work sponsored by an agency of the United States Governt Neither the United States Government nor any agency thereof, nor any of their employes, makes any warranty, express or implied, or assumes any legal liability or responsibility for the accuracy, completeness, or usefulness of an: information, apparatus, product, or process disclosed, or represents that its use would not iniringe privately owned rights. Reference herein to any specific commercial product, process, or service by trade name, trademark, manufacturer, or otherwise does not necessarily constitute or imply its endorsement, recommendation, or favoring by the United States Government or any agency thereof. The views and opinions of authors expressed herein do not necessarily state or reflect those of the United States Government or any agency thereof. 

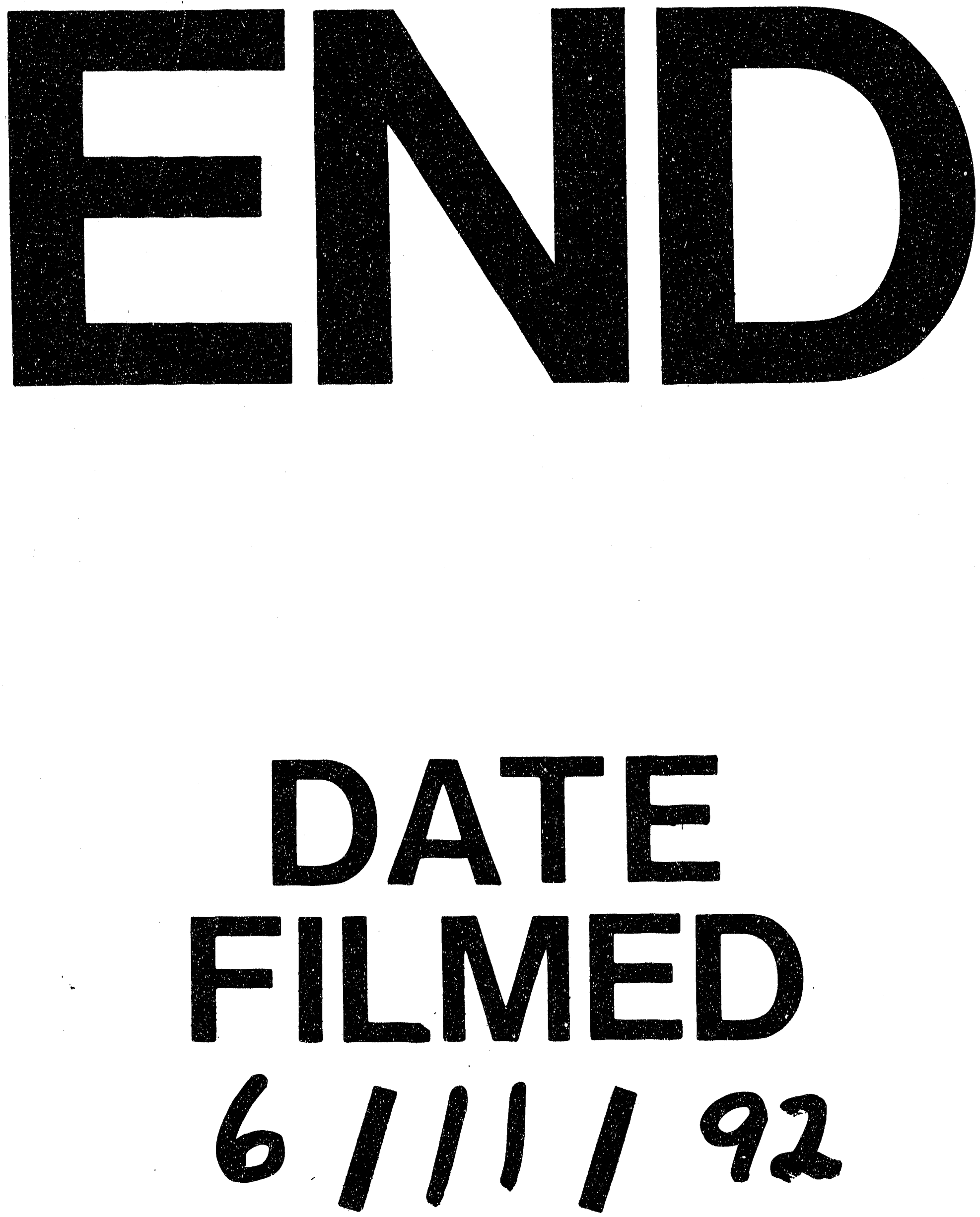
1 